\title{
Successful Treatment of Refractory Diamond-Blackfan Anemia Using Metoclopramide and Prednisolone
}

\section{Tedaviye Dirençli Diamond-Blackfan Anemisinin Metoklopramid ve Prednizolon ile Başarılı Tedavisi}

\author{
Barış Malbora, Zekai Avcı, Namık Özbek \\ Baskent University, School of Medicine, Department of Pediatric Hematology, Ankara, Turkey
}

\section{To the Editor,}

Diamond-Blackfan anemia (DBA) is a rare congenital hypoplastic anemia characterized by severe normochromic-macrocytic anemia, reticulocytopenia, a decrease in the number or absence of bone marrow erythroid precursor cells, and normal megakaryocytic and granulocytic differentiation [1-4]. Herein we report the successful treatment of steroid-refractory DBA in a 10-month-old male using prednisolone plus metoclopramide.

The patient was referred to our hospital for evaluation of severe anemia. The first indication of severe anemia occurred 2 months earlier. He received red blood cell transfusion at that time. Physical examination at admission to our hospital showed the infant was pale. Laboratory findings were as follows: hemoglobin ( $\mathrm{Hb})$ level: $4.5 \mathrm{~g}$ $\mathrm{dL}^{-1}$; mean corpuscular volume (MCV): $73 \mathrm{fL}$; red cell distribution width: $21.6 \%$; reticulocyte count: $0.44 \%$; white blood cell count: $14.9 \times 10^{9} \mathrm{~L}^{-1}$; platelet count: $391 \times 10^{9}$ $\mathrm{L}^{-1}$. Hypochromic microcytic erythrocytes, normochromic erythrocytes, macrocytic erythrocytes, and normal platelets were also noted. Biochemical and urine analyses were normal. $\mathrm{Hb}$ electrophoresis showed an elevated $\mathrm{HbA} 2$ level in the patient $(4.1 \%)$ and in his father (4.3\%), which was compatible with the $\beta$-thalassemia trait. The patient's red cell adenosine deaminase level (1321 $\mathrm{IU} \mathrm{L}^{-1}$ ) was high (reference: $788 \mathrm{IU} \mathrm{L}^{-1}$ ). Bone marrow aspiration biopsy showed decreased erythropoiesis, with normal myeloid precursors and megakaryocytes.
The patient was given prednisolone $2 \mathrm{mg} \cdot \mathrm{kg}^{-1} \cdot \mathrm{d}^{-1}$ for 1 month, but did not respond, and was then treated with a tapered regimen of high-dose methylprednisolone (30 mg. $\mathrm{kg}^{-1} \cdot \mathrm{d}^{-1}$ for $3 \mathrm{~d}$, followed by $20 \mathrm{mg} \cdot \mathrm{kg}^{-1} \cdot \mathrm{d}^{-1}$ for $4 \mathrm{~d}$ ), and again no improvement was observed. The patient received red blood cell transfusion twice during corticosteroid therapy to treat severe anemia. Due to resistance to steroid treatment, we initiated metoclopramide $0.3 \mathrm{mg} \cdot \mathrm{kg}^{-1} \cdot \mathrm{d}^{-1}$ (3 times daily). On the day 28 of metoclopramide therapy the patient's $\mathrm{Hb}$ level increased to $10.7 \mathrm{~g} \mathrm{dL}^{-1}$. Steroid treatment was reduced, and then withdrawn after metoclopromide therapy was initiated. The patient's Hb level was 5.5 $\mathrm{g} \mathrm{dL}^{-1}$ and his reticulocyte count was $2.4 \%$ after 6 months of metoclopromide treatment. Pulse steroid was given, the steroid dose was reduced to $1 \mathrm{mg} \cdot \mathrm{kg}^{-1} \cdot \mathrm{d}^{-1}$, and the metoclopromide dose was increased to $0.5 \mathrm{mg} \cdot \mathrm{kg}^{-1} \cdot \mathrm{d}^{-1}$. Metoclopramide was decreased to $0.2 \mathrm{mg} \cdot \mathrm{kg}^{-1} \cdot \mathrm{d}^{-1}$ (twice daily administration) and steroid was decreased to $0.25 \mathrm{mg} \cdot \mathrm{kg}^{-}$ ${ }^{1} \cdot \mathrm{d}^{-1}$ after 2 years of treatment. At the time this report was prepared the patient had been receiving metoclopramide without steroids for 7 months, and his Hb level was within normal limits (Figure 1).

Several medications have been used to treat both steroid-dependent and steroid-refractory DBA patients [1,4]. Metoclopramide induces prolactin release, which improves erythropoiesis indirectly-possibly mediated via bone marrow microenvironmental cells released by the pituitary gland $[5,6]$. Recently, metoclopramide has been shown to be an effective therapy for DBA $[5,6,8]$. Abkowitz et al. [5]

Address for Correspondence: Barış MALBORA, M.D.,

Başkent Üniversitesi Tıp Fakültesi, Çocuk Hematoloji Bilim Dalı, Ankara, Turkey

Phone: +90 3122126868 E-mail: barismalbora@gmail.com

Received/Geliş tarihi : April 17, 2011

Accepted/Kabul tarihi : November 14, 2011 


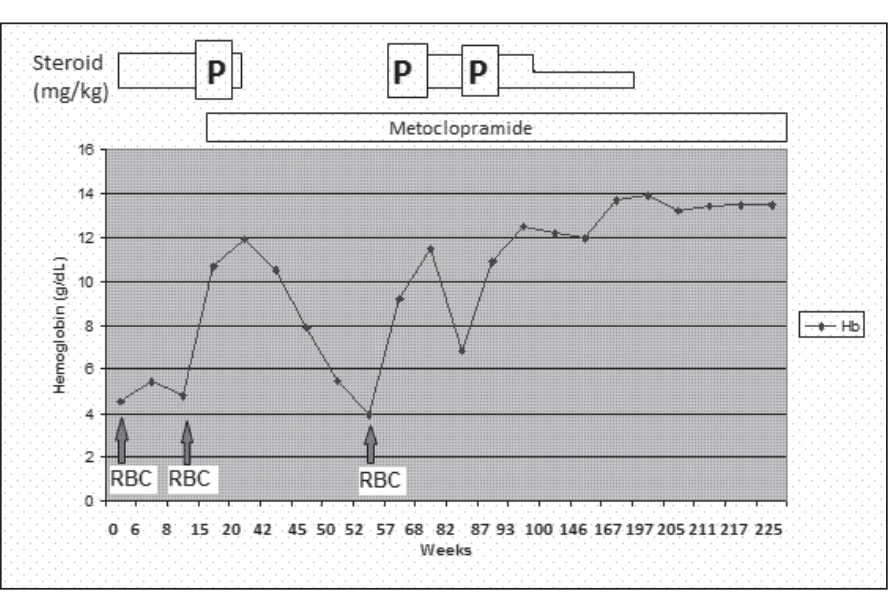

Figure 1: The patient's hemoglobin values and the drugs he was administered.

PS: Pulse steroid; RBCT: red blood cell transfusion.

reported that a DBA patient of theirs with pure red cell aplasia transiently improved during pregnancy and lactation. This improvement was associated with an increase in the secretion of prolactin. Following this index case, other researchers used metoclopramide to treat 9 patients with DBA that were refractory to other therapies, and 3 of them responded. Metoclopramide was successfully used in the presented patient, who did not respond to treatment with standard-dose and high-dose methylprednisolone.

The adverse effects of metoclopramide include agitation, fatigue, headache, extrapyramidal reactions, and hyperprolactinemia. It was reported that hyperprolactinemia has a carcinogenic effect in rodents and humans; it also increases the risk of breast cancer in pre- and post-menopausal women. Nonetheless, the relationship between hyperprolactinemia and prostate cancer is not as strong as its relationship with breast cancer [9]. The relationship between the serum prolactin level and cancer has not been established in childhood, which necessitates further research. Treatment with metoclopramide was effective in the presented patient. Because this agent is relatively inexpensive and safe for patients with DBA that are refractory to steroids, we think that metoclopramide can be considered a drug of choice for patients with DBA.

\section{Acknowledgement}

Oral and written informed consent was obtained from the patient's parent. The present case report protocol conformed to the principles outlined in the Declaration of Helsinki (1975) and later revisions, and was approved by the Baskent University, School of Medicine Ethics Committee, Ankara, Turkey.

\section{Conflict of Interest Statement}

None of the authors have any conflicts of interest, including specific financial interests, relationships, and/ or affiliations, relevant to the subject matter or materials included in this manuscript.

\section{References}

1. Flygare J, Karlsson S: Diamond-Blackfan anemia: Erythropoiesis lost in translation. Blood 2007; 109 (8): 3152- 3154

2. Lipton JM, Atsidaftos E, Zyskind I, Vlachos A: Improving clinical care and elucidating the pathophysiology of Diamond Blackfan anemia: An update from the Diamond Blackfan Anemia Registry. Pediatr Blood Cancer 2006; 46: 558-564

3. Da Costa L, Willig TN, Fixler J, Mohandas N, Tchernia G: Diamond-Blackfan Anemia. Curr Opin Pediatr 2001; 13: 10-15

4. Willig TN, Gazda H, Sieff CA: Diamond-Blackfan anemia. Curr Opin Hematol 2000; 7 (2): 85-94

5. Abkowitz JL, Schaison G, Boulad F, Brown DL, Buchanan GR, Johnson CA, Murray JC, Sabo KM: Response of Diamond-Blackfan Anemia to metoclopramide: Evidence for a role for prolactin in erythropoiesis. Blood 2002; 100: 2687-2691

6. Akiyama M, Yanagisawa T, Yuza Y, Yokoi K, Ariga M, Fujisawa K, Hoshi Y, Eto Y: Successful treatment of Diamond-Blackfan Anemia with metoclopramide. Am J Hematol 2005;78:295-298

7. Diamond LK, Blackfan KD: Hypoplastic anemia. Am J Dis Child 1938; 56: 464-467

8. Nawel G, Fethi M, Kouki R, Mohamed B: Successful treatment of Diamond Blackfan anemia with metoclopramide. J Pediatr Hematol Oncol 2007; 29 (10): 728

9. Harvey PW, Everett DJ, Springall CJ: Adverse effects of prolactin in rodents and humans: Breast and prostate cancer. J Psychopharmacol 2008; 22: 20-27 